\title{
Book Reviews, Part 1
}

\section{Everyone should be reading}

\section{Davis, D. R. (2013). The Bible Speaks Today: The Message of Daniel. Nottingham: IVP.}

Dale Ralph Davis is one of those skilled expositors who continually builds on his lifetime of immersion in the Hebrew and Aramaic texts of the Old Testament, bringing complex texts to life in fresh and challenging ways. The Message of Daniel is no exception, and I would wholeheartedly recommend this short commentary for anyone who wishes to study the book for themselves or preach from it. It would also be of great value for anyone engaged in more serious academic work, since although it does not tackle many of the Danielic controversies in any great detail, it does clearly and concisely set out cogent arguments and provide plenty of references for where further reading is to be found.

Davis has written a replacement for Robert Wallace's 1979 contribution to the BST series. He is a conservative evangelical scholar, who argues for an early date of the text, which he regards as a 'realistic survival manual for the saints.' One of the great strengths of the exposition is that it treats the text as a unity, and whilst the linguistic peculiarity of the switch from Hebrew to Aramaic and back again is acknowledged, and the shift in style also carefully discussed, Davis is clear that the book of Daniel is a whole, with a coherent message that we can all benefit from heeding. I was particularly struck by his readiness to acknowledge complexity, and simply to say that at times the details are difficult to understand (the discussion of 9:24-27 focuses on the big picture and includes the admission that he does not understand all the details). Slightly unusually for a book in the BST series, Davis works primarily from his own translation of the text, and it is a shame that this was not included in its entirety, either chapter by chapter, or as an appendix. Some readers may also find his tendency to rely heavily on the American Civil War and the Second World War as sources of illustrations a bit wearing, but this is only a minor issue.

I found fresh and challenging insights throughout the exposition. The message of chapter 2 is that 'we are to serve where we have been placed within the fading kingdom as we go on waiting for the final kingdom' (47). The real miracle in Daniel 6 is, of course, that Daniel continued faithful in prayer, rather than that the lions' mouths were closed. Daniel 9 calls me to confess the sins of my nation as well as my own. I could go on, but I hope this is enough to make the point that this short commentary is one every serious student of the Bible should read.

Tom Wilson

Anvil Reviews Editor 


\section{Thiselton, A. C. (2013). The Holy Spirit: In biblical teaching, through the centuries, and today. London: SPCK.}

I found this book an absorbing read, making eight hours spent on trains pass with remarkable speed. A lifetime of teaching and writing have borne fruit in another excellent book from a renowned teacher. The book is divided into three sections: the first covers the Holy Spirit in Biblical teaching (also taking in the intertestamental literature); the second the Holy Spirit through the centuries (from the Apostolic Fathers to the eighteenth century); and the third the Holy Spirit in Modern Theology and today. Building on a solid foundation of Biblical exegesis in part one, Thiselton embarks on a whistle-stop tour of teaching and writing and experience of the Holy Spirit down the ages before slowing the pace considerably to discuss the twentieth and twenty-first centuries, with a particular focus on the Pentecostal and Renewal Movements. His breadth of reading and command of the subject is truly impressive, especially in the discussions of the particular emphases of different authors down the centuries. Another particular strength of the book is the willingness to learn from history, with frequent parallels being drawn between the period of history under discussion and the present day. To give one example, when discussing the twelfth and thirteen century movement of the Cathars, who opposed the church in Rome, he notes their claims of experience of 'baptism in the Holy Spirit,' often by laying on of hands, something many modern Pentecostals might recognise.

As a world-renowned expert in hermeneutics, it is unsurprising that there are several discussions of hermeneutical issues in relation to understanding the Holy Spirit. Thiselton is clear on the danger of sloppy use of terms such as 'presupposition,' the dangers of an uncritical embrace of post-modernism and the need for critical self-reflection. Thiselton's Anglican heritage is clear in his desire to build bridges between his own understanding and that of other theologians. He is especially keen to develop dialogue with Pentecostal and Renewal Movement scholars, and is careful in his treatment of their writings, but also appeals for the maturity that is necessary for critical dialogue. He is, by his own admission, not entirely comfortable with a more Pentecostal style of church service, but that does not mean he is unwilling to learn and engage in theological discussion; a reminder that age does not necessarily make one more entrenched in one's views.

The final chapter should perhaps have been in a section of its own. The tone and character is remarkably different from what goes before. After twenty-three chapters of careful analysis and critical engagement, Thiselton engages in a more personal reflection, outlining seven fundamental themes of his study, before engaging in dialogue with Pentecostals and advocates of the renewal movement and finally some closing reflections on the implications of his book for hermeneutics and biblical interpretation. This is Thiselton at his best: erudite, clear and persuasive. My only gripe with the book was the tendency to switch between first person singular and plural; the plural grated at times, and the retention of the singular throughout the final chapter made it all the easier to read. At five hundred pages, this is not a short book, but the breadth and depth of discussion mean an awful lot is crammed into a 
relatively short space. If you only want to have one book on the person of the Holy Spirit on your bookshelf, I suggest this should be it.

Tom Wilson

Anvil Reviews Editor

\section{Biblical Studies}

Bridge, F \& Butler, J. T. (Eds.) (2012). Conversations on the Edges of Things: Reflections for the Church in Honor of John Goldingay. Eugene: Pickwick Publications/Wipf \& Stock.

This is an extraordinarily moving book that pays handsome and appropriate tribute to one of the most renowned British biblical scholars in the post-war era. John Goldingay's life and work - a ministry of both writing and teaching in seminaries, primarily - has spanned both Britain and the USA, and is rightly celebrated in this touching and moving volume. Francis Bridger and James T. Butler have done a more than commendable job of assembling a wideranging collection of voices, essays and other contributions, and who are all drawn from John's career. The volume celebrates Goldingay's seventieth birthday, and pays tribute to his lifetime of service to the Church and academy.

It is reasonable to estimate that Goldingay's career has touched the lives of at least a few thousand seminarians. And therefore, his writings, teaching and insights have touched the lives of hundreds of thousands in our congregations and churches. It is a sobering thought. That in dedicating most of his academic life to just a couple of seminaries, and in inspiring his students to read and understand the Bible in new ways, Goldingay has probably shaped more ministries and churches than many itinerant preachers. But that is perhaps the point. By being rooted and grounded in two such fine institutions, Goldingay's vivid theological outlook, his visionary pedagogy and insightful hermeneutics have radiated outwards and touched more places than he ever could have visited in person. The book bears testimony to that. The seeds that have flown on the wind have borne fruit in new places. This collection is some of that fruit; gathered so we can give thanks for the harvest.

Martyn Percy

Ripon College, Cuddesdon, Oxford

Cole, G (2013). The God who became Human. Nottingham: InterVarsity Press.

In The God who became Human, one of the recent volumes in the New Studies in Biblical Theology series, Graham Cole seeks an answer to a question that has been plaguing Christian scholars and theologians for ages: why exactly did God become human? Cole attempts to answer this question through examining the theme of incarnation throughout Scripture from beginning to end. His goal specifically is to determine whether or not incarnation was a part of the hope of Israel. Cole finds evidence that the incarnation, God coming into existence in 
human form, was God's plan all along, but determines that this plan would have been unexpected to God's people during Old Testament times.

Throughout the first half of the book Graham explores and traces the concept of incarnation throughout the Old Testament. He concludes that 'the incarnation per se was not explicitly part of the Old Testament hope' (11), but that nevertheless the concept exists subtly throughout the Hebrew Bible. Cole begins by exploring the idea of concomitance (the Godwith-us motif). Cole also interestingly points out that God is almost exclusively described in the Old Testament using the literary tools of anthropopraxism (human actions), anthropopathism (human emotions), and anthropomorphism (human physicality). It seems as though this presents a foundation for an incarnational theology. After introducing these ideas, Cole draws them out further, taking a look at various theophanies in Old Testament stories, paying particular attention to those in which God appears in the form of a man.

After having explored the concept of incarnation throughout the Old Testament, the next three chapters deal more closely with the idea of incarnation itself. Cole begins by taking a close look at 'the great mystery' of the incarnation according to the New Testament authors (Chapter 4) before attempting to answer the question of why did God become human. He looks to scripture and ultimately presents six answers to this question. Cole's insight is very powerful, and he helps the reader understand that God's plan is uniquely fulfilled through the incarnation, in which God becomes like us. Finally, Cole presents a detailed study of the theological and existential significance of the incarnation.

The only shortcoming of the book is its limits due to the length. Attempting to cover a topic as important to the Christian faith as incarnation in just over 150 pages will naturally result in some things being omitted or glossed over. In fact, Cole did an excellent job covering such a variety of material in such a short space, but a few ideas and examples could have been drawn out further to improve the quality of his arguments.

Overall I recommend this book to anyone seeking to ground their faith and theology in Scripture. This book is relatively short, and somehow manages to be both academic and easy to read. The New Studies in Biblical Theology series as a whole attempts to reach Christians of all levels, and Graham Cole does an excellent job of engaging the mind and heart in a way that will draw readers in regardless of age and education. This book is great for Pastors and lay leaders, as well as members of the congregation seeking to deeper understand the theology of incarnation present in Scripture. The only caveat I have to offer would be that those seeking to do an exhaustive study of Incarnation should look to supplement this book with other such works.

Chris Verbracken

Bethel Seminary (Saint Paul, MN) 
Dell, K. J. \& Joyce, P. M. (Eds.) (2013). Biblical Interpretation and Method: Essays in Honour of John Barton. Oxford: Oxford University Press.

Some 24 scholars offer essays on the issues around biblical Interpretation in honour of John Barton well known for his tenure at Oxford University and his interest in the areas suggested by the title. The Festschrift also includes an index of his works and reviews (eleven pages!). As the cover blurb says, the first section 'revisiting Older Approaches' looks at old friends like Form Criticism through detailed examination of certain texts whilst the second part looks at newer methods such as Postcolonial or Feminist readings.

As an example, John Day looks at the possible links between ANE flood stories and Genesis in the chapter on Comparative Ancient Near Eastern Study. He admits that the exact detail of how the Bible absorbed earlier traditions (and is sceptical about attempts from folk like Wenham and Millard from a more conservative perspective) cannot be clear but he is sure that it did take over aspects of pagan stories though not uncritically and in with its own theological assumptions. It is clearly laid out but one wonders what exactly is new here (a comment I find about several of the chapters).

In the second half of the book, for example, we have a useful essay by Paula Gooder on Feminist criticism (noting how it has broken down in many categories) in which she provides a summary of the state of play on Paul and women's ministry suggesting that categories such as egalitarian or patriarchal don't quite fit the bill.

Many of the chapters give helpful discussion of the history of the particular form of interpretation being examined. The book would help those wanting to understand more of the varying approaches to understanding the bible but one would suggest that really to benefit from this volume some understanding of the basic issues is essential (i.e. this is not for a first year student but those further down the line would benefit greatly).

Peter Ballantine

Milton Keynes

Hoek, M., Ingleby, J., Kingston-Smith, A. \& Kingston-Smith, C. (Eds.) 2013. Carnival Kingdom - Biblical Justice for Global Communities. Gloucester: Wide Margin.

The theme of Carnival, with its connotations of revelling and feasting in defiance of imposed order and oppression, is introduced by Joel Edwards, a former Director of the Evangelical Alliance UK, at the beginning of his Foreword to this collection of 12 substantial essays: 'When black slaves stared at each other across the campfire and sung "Steal away to Jesus" within earshot of their slave masters, a carnival was taking place.'

Jonathan Ingleby in his Introduction then promotes a similar idea of Carnival by quoting Rowan Williams' comments on C.S. Lewis's Narnia writings and the action of Aslan by which 
the challenge to 'the orderliness of a world focussed on the self' culminates in a free-for-all revel. This is then linked to 'the revolutionary Biblical justice' that calls into question 'the customary order by which the rich and powerful rule to their own advantage, and the poor and the weak take what scraps they can get.' Hence the title 'Carnival Kingdom' given to this book. It links the essays, even if their material and arguments are very diverse, spanning different specialisms and geographical contexts.

The first essay is by Carol Kingston-Smith. She starts from the Medieval Carnival, 'a revolutionary and alternative view of reality; a way of representing, if only for a short time, a new reality in which the present order was turned on its head in favour of those from the underside of history: the peasant, the poor, in short the non-elite.' She pursues these ideas at length, concentrating on the twin carnival themes of laughter and the banquet, alike from within the Bible and in the teachings for today of the Slovenian Slavoj Zizek and the Brazilian Paolo Freire, inviting us afresh 'to examine where our primary allegiances lie.'

Dario Lopez Rodriguez writes on 'The Liberating Dimension of the Kingdom of God'; he is a Pentecostal pastor in Lima, Peru, where 'he was born and grew up in abject poverty,' but was later able to gain a PhD through the Oxford Centre of Mission Studies. His article gives account of the difficulties evangelical churches have had to face to be able to 'proclaim the Kingdom of God with words and concrete actions of love for our neighbour within situations of institutionalised violence - racism, exclusion, marginalisation, poverty.' Towards the end he sums up with these words: 'evangelical church leaders or leadership teams need to start to promote new models of social and political leadership from the ground up, social and political leaders who actively participate in social movements and in local governments such as mayors or councillors... they need to be exemplary models of transparent public management, with periodic accountability, allowing all citizens and neighbours free access to information, continually being open to inquiry.'

Martin and Margot Hodson in 'Climate Justice' combine their scientific and theological specialisms, by giving a clear picture and warning about the extent and effects of global warming as we move into the probable future. Then a shorter but equally trenchant account of such international policy-making as has taken place to the end of 2012 - ending with a warning from Tearfund that it is the poor who have done the least to cause climate change, yet are those most seriously affected by it and who have the smallest voice on the international stage where decisions are made. After considering the various possibilities of action tried so far, the chapter ends with a thorough examination of how the biblical guiding texts have found some appropriate translation into action, even if the target of restricting the rise of temperature to two degrees above pre-industrial times now seems unlikely to be met.

Space only allows a mention of the other contributions, including those from India, Sweden and the Philippines, several of them focussed on how biblical material can relate to today's 
circumstances and challenges. One would be surprised if every article is equally helpful to every reader, but there will doubtless be several which prove usefully significant to Anvil readers.

\section{Martin Conway}

Oxford

\section{Old Testament Studies}

\section{Boda, M. J. \& McConville, G. (Eds.) 2012. Dictionary of the Old Testament Prophets. Downers Grove: IVP Academic.}

This is the eighth volume in the Black Dictionary series and like previous volumes, it is intended to provide up-to-date, accessible scholarship. It is well up to the standard of earlier volumes and will undoubtedly be a valuable resource for many years to come.

The range of this dictionary is impressive. Its aim is to provide a substantial overview of the prophetic literature and in that sense it will supplement more detailed commentaries. To take a typical example, the article on Isaiah by Hugh Williamson covers the following: 1. Structure and content. 2. Survey of scholarship. 3. The text of the book of Isaiah. 4. Two Major Theological Themes. 5. King and Messiah. Williamson accepts the majority view that chapters 40-55 should be ascribed to the work of a great prophet of the Babylonian exile. The remaining chapters 56-66 are more difficult to assess. There is a separate article by B.H. Lim on the history of the interpretation of Isaiah.

However, the range of this dictionary is far wider than the prophetic books themselves. There are numerous articles on particular aspects of the genre. These include for example Eschatology, Dead Sea Scrolls, Cosmology, Canonical Criticism, Covenant, Form Criticism, Hebrew Language. There is also a most helpful article on Hermeneutics (interpretation) by Richard Briggs. In all there are 115 articles probing questions new and old. Another helpful feature is a guide to how to use the dictionary with extensive cross-referencing.

Bibliographies too are substantial. Since this volume is multi-authored, there is no uniformity of standpoint, although the general approach seems to be moderately conservative.

Unsurprisingly therefore, there are no articles dealing with inspiration or authority.

This 'Compendium of Contemporary Biblical Scholarship' in common with earlier volumes in the series will prove invaluable to both scholars and theological students. It is to be hoped too that others, especially clergy, will find it helpful in bridging the chasm that frequently exists between the Academy and the pew.

Howard Bigg

Cambridge 


\section{New Testament Studies}

\section{Tilling, C. (2012). Paul's Divine Christology. Tübingen: Mohr Siebeck.}

Paul's Divine Christology by Chris Tilling offers a substantial contribution to the Pauline divine-Christology debate. Tilling is forthcoming in his claim that the debate has been crippled by a failure to 'grasp sufficiently' that which is 'most obvious, namely Paul's own language' (3). With corrective intent, Tilling aims to 'refocus' the debate upon the exegetical data, as well as more broadly to 're-engage' with the 'sweep of themes in Paul's letters' (5). By this, he believes we can uncover the pattern of data which grants epistemological access to Paul's Christology-a pattern of data which Tilling terms, the 'Christ-relation'. That is, by assessing the relationship between believers and Christ in Paul's letters, we find a pattern of data that the Apostle himself would have recognised: a pattern of data replete with 'themes and concepts that, in the Jewish scriptures, describe the relation between Israel and Yhwh' (7). Therefore, Tilling concludes that this 'Christ-relation is Paul's divine-Christology' (8), for it is a relationship expressed by the same means that monotheistic Judaism 'expressed the transcendent uniqueness of God' (244). Whilst minor questions are raised regarding Tilling's approach to the Pauline corpus, his exegetical analysis of the OT, and his treatment of the 'union with Christ' theme, this work is a most welcome (perhaps overdue?) evangelical contribution to the debate.

In order to explain the necessity and goal of his own contribution, Tilling begins by tracing the debate's history. Strikingly, he does not critique advocates of a 'low' Christology (like Dunn), but those with whom he identifies most closely in the debate: Fee, Hurtado, and Bauckham. To various extents, Tilling questions the entire methodological grounds for their arguments. This is the decisive move in Tilling's historico-theological analysis-and certainly the boldest.

Tilling argues that we cannot study Paul's Christology until we understand his Jewish faith in God. Building upon scholars who emphasise the importance of relationship within OT faith, Tilling concludes that the essence of Jewish monotheism was 'a loving commitment to God over against idolatry' (67), and that therefore, we should expect Paul to express the uniqueness of God in equally relational terms (71-72).

Tilling now turns to his central task: an exhaustive search of Paul's 'undisputed letters' for Christ-relation data. But which letters are 'undisputed', and why? Surprisingly, no list of 'disputed' letters is ever given, nor is any argumentation for their status offered. Perhaps Tilling has conceded ground in order to have an audience with critical scholarship. But if so, can one appropriately claim to have grasped a Pauline Christology without a single reference to Ephesians, Colossians, 2 Thessalonians, or the Pastorals? Furthermore, what if some parts of these 'disputed' letters lend themselves more directly to issues of ontology, divineidentity, or cultic-devotion-and not to the 'Christ-relation' pattern? By neglecting to even consider these possibilities, Tilling is vulnerable to criticism. 
The omission is a shame, given that the exegetical work he does in the 'undisputed letters' is of the highest class (105-180). Tilling probes deep into Paul's understanding of the believer's relationship with the risen Lord Jesus. He creates nine broad thematic domains under which he collates his finding, ranging, for example, from the Christ-focused goals and motivations of Paul to a careful study of the simultaneous absence and presence of Christ in the lives of believers. To systematise relational data such as this-data which is often enigmatic, subtle, and resistant to scientific categorisation-without atomising the results or crushing the delicate material, is an impressive feat. It is a master class of NT exegesis and theology.

His other body of evidence is Paul's 'in Christ' language. For Tilling, the centrality and extent of such a relational concept indicates that the Christ-relation was a 'unified existential reality' for Paul (183). But Tilling leaves this theme vastly underutilised. 'Union with Christ' could have been the trump card-a dynamic element holding disparate themes togetherbut it is assumed, not demonstrated. This creates notable shortcomings. For example, Tilling believes that there is no 'material of direct relevance' to the Christ-relation pattern of data in Romans 3-6 (181). If Paul expresses his Christology by means of the Christ-relation (as Tilling argues), to conclude that these chapters contribute little to Paul's Christology would be alarming. And yet, Tilling's work contains no sustained discussion of the cross, atonement, or resurrection, which is disappointing. A better appreciation of union with Christ (which pervades passages like Romans 5-6) would have taken Tilling deeper into the heart of Paul's Christ-relation, bringing the discussion into richer communication with his soteriology.

Tilling turns next to address the tricky issue of the Second Temple literature. Some dismiss the findings of Bauckham and Hurtado on the evidence that in such texts, we find 'the resources to understand devotion to the risen Lord in a way that did not mean they must break with Jewish monotheism' (196). Tilling takes up the challenge with a generous seriousness, despite believing that their argument depends on 'scraps of largely irrelevant texts' (233). In a brilliant turning of the tables, Tilling uses their own data against them. He explores in the Second Temple texts the same nine relational domains found in Paul's writings. What he finds is that God, not any other exalted being, is the only possible influence upon Paul's Christology from these texts (if indeed, Paul drew upon them at all!). For, 'The God-relation language in these texts is almost exactly the same complex of interrelated themes that one finds in Paul's Christ-relation language' (206). His analysis of the Second Temple data is thorough, and the comparison with the Pauline Christ-relation compelling. His overall thesis may have been strengthened had he employed the same exegetical skills in a more complete study of the OT Yhwh-relation pattern of data.

I agree with Tilling's closing reflections on the strengths of his approach. Firstly, he has built on the underdeveloped lines of Fee, Hurtado and Bauckham, whom he (belatedly) congratulates for 'looking in the right direction' (257). Secondly, he has engaged the letters of Paul on their own relational terms, as texts written 'not to detail an abstract theology but 
rather to instruct and encourage precisely the focus of this study, the Christ-relation.' (256). Tilling has contributed an enormous amount to the debate, and offers an exciting invitation, '...one can now look for the elements of this Christ-relation, itself the shape of Paul's divineChristology' (256). And we agree that a further 'look' would be valuable in the following areas:

a) A systematic exegetical analysis of the OT, mirroring Tilling's commendable work in the NT, which explores the Yhwh-relation data;

b) An exploration of how 'union with Christ' further integrates the Christ-relation data;

c) The methodology of this book ought to be applied to Paul's 'disputed' letters.

Thought-provoking, eminently readable, and genuinely edifying, Tilling's work deserves a wide readership amongst experts and students alike.

\section{Matthew Dodd}

Moore Theological College, Sydney, Australia

\section{Doctrine and Philosophy}

\section{Astley, J. \& Francis, L. J. (Eds.) (2013). Exploring Ordinary Theology: Everyday Christian Believing and the Church. Farnham: Ashgate.}

The more I engage in pastoral ministry and church leadership, the more clearly I have recognised the distinction between doctrinal and lived religion. There are the official teachings of the Church, both in terms of the Catholic creeds and official statements of faith, as well as the writings and debates of different academic theologians. This is what one might term doctrinal religion. Academic theology strives for precision in this area, attempting to define precisely what it is Christians (a term that is often left undefined) believe. Lived religion by contrast looks at what those who self identify as believers in a particular religious faith actually do. A few examples may illustrate the distinction. Doctrinally, Christianity teaches sacrificial financial giving. Some believe the teaching of the Church should be a tithe, giving ten percent of income (either pre-tax or after tax) to the work of the church. Others do not stipulate a figure, but nevertheless expect significant generosity. Yet anyone who had ever been involved with church finances knows that the vast majority of giving comes from a relative minority of church members. The Church of England's oft-quoted suggestion that a gift of mere five per cent of post-tax income to the church from every regular churchgoer would more than solve the Church's current financial problems illustrates the distinction. Thus doctrinal religion may say one thing about financial giving, but lived religion says something quite different, in this case, something far less challenging.

If this is the reality of ministry, then how are we to make sense of it? The edited volume Exploring Ordinary Theology offers some useful tools both for church leaders and also for those who wish to engage in more formal academic study of these questions. The book is divided into two parts. The first reflects on the nature of ordinary theology and the second 
offers some practical examples of the process. In the first part, there are five reflections. Broadly speaking, ordinary theology is defined as critical reflection on their beliefs by those who have appropriated those beliefs for themselves but have not engaged in any formal academic theological education. The distinction between the 'father tongue', the language of power and authority as the language of academic theology and the 'mother tongue,' the language learned in infancy as the language of ordinary theology illustrates the thinking behind this movement.

The second part is given to fourteen examples of ordinary theology. Three examples will suffice: Ann Christie reflects on her fieldwork which demonstrated how the majority of those Christians she interviewed thought of Jesus' salvific role primarily as a moral example. Leslie Francis explores how different psychological types (sensing versus intuitive; thinking versus feeling) read the Bible. Tania ap Siôn discusses the prayers recorded in Bangor Cathedral's prayer board. Each essay is interesting reading, and the range of voices is both a strength and a weakness: a strength because it illustrates the diversity of voices within the ordinary theology movement and a weakness because of the lack of a single clear thread running through them all.

One of the strengths of Exploring Ordinary Theology is the range of theological perspectives, which includes Catholic, Anglican and Assemblies of God. I found this volume very stimulating reading for two reasons. The first is from an academic perspective: as someone who is interested in practical theological research, there was much food for critical reflection. The second is as a preacher: this book is a helpful reminder of the difference between the official teachings of the church and what many ordinary Christians and churchgoers actually believe. Armstrong's chapter on views of life after death is one that I will return to when thinking about how to preach at funerals. I would therefore commend it both to those with an academic interest in practical theology and also to any who wish to critically reflect on their own preaching.

Tom Wilson

Anvil Reviews Editor

\section{Busch, E. (2010). Drawn to Freedom: Christian Faith Today in Conversation with the Heidelberg Catechism. W.H. Rader (Tr.). Grand Rapids: Eerdmans.}

In this translation of a work previously published in German, Eberhard Busch offers a 'conversation' or commentary that seeks to relate one of the great statements of the Reformed tradition, the Heidelberg Catechism (1563), to contemporary Christian life and thought.

Drawn to Freedom begins with an introductory chapter where two preliminary tasks are undertaken. First, Busch considers the nature of theology and the 'right' way of doing theology. Given his Reformed tradition and Barthian approach, it is no surprise that he understands good theology as theology which begins with God's revelation in Christ and the unexpected, gracious address of God to humanity. He distinguishes this from natural or 
liberal theologies that proceed on the basis of an assumed openness to God inherent in humanity and begin with analysis of the human condition. Second, Busch offers an authoritative introduction to the 'companion volume' - the Heidelberg Catechism itself. He covers the historical context out of which the catechism arose and explains the structure of the book and the thinking and assumptions that underlie this structure. The remainder of the book works through the catechism, addressing each of the 129 articles in turn in three sections: 'God's deliverance of the captive' (1-22); 'The free God' (23-85); and 'The free human being' (86-129).

This is a scholarly, erudite and committed work. However, it is neither easily accessible nor readily applicable. The arguments are dense and involved and at times it is longer than necessary and overly wordy. It is less a book for the general reader and more a book for those with a particular interest in the history of the reformation or the academic reception of classic reformation thought in the contemporary context.

If there is a compelling reason for the non-specialist reader to consider at least a limited, strategic engagement, this reason will be found in Busch's emphasis on 'freedom'. The theologian Richard Bauckham has noted that in Western societies 'freedom is becoming almost the only common value' and 'Freedom is one of the most potent words in the modern age. Perhaps it is the most potent word of all - or rivalled only by love.' Likewise, the translator of Drawn to Freedom, William Rader, notes: 'freedom is spoken of a great deal... Yet there often does not seem to be reflection about what the word "freedom" means' (viii). In this context, Busch's attentiveness to what "freedom" means in light of the Christian gospel is timely and important. From Busch, we learn that 'God favours freedom (Zwingli)' and that 'God is so committed to freedom that God wants to give [un-free] humans their own freedom.' (xi) According to Busch, the freedom that God gives is distinctive, notably different to the notions of freedom at play in liberal democracies. Somewhat counter-intuitively, our freedom is in our 'belonging' to Jesus Christ. 'Through him and in him I am freed - from abandonment to alien rulers, but also from the "tyrant in my own breast".' (43) In belonging to Christ we are released from the 'damaged and damaging freedom' of 'godless and inhumane humans, in essence mere egos, humans curved back into themselves' (77). Instead, 'In true freedom our free choice can be nothing other than the choice for coexistence, freedom in and for living together with God and all those loved by God' (258). This is a message our increasingly disenchanted and ever more atomized culture desperately needs to hear.

Drawn to Freedom is an important work by one of the preeminent Reformed theologians in the world today. It might not be worth a big investment of time from ministers and other practitioners but for specialists, it will more than repay the time invested in close reading and consideration.

Jonathan Brant

Oxford Pastorate Chaplain 


\section{Squire, A. (2010). Asking the Fathers. London: SPCK.}

I find it difficult to praise this book too highly. Stimulating, challenging, encouraging, heartwarming. It was first published in 1973 and a new edition in 1994. It has now been reissued by SPCK in their Classics series. Squire was a Dominican monk who died in 1997. The blurb says that 'since its first publication, Asking the Fathers has been acclaimed as a classic introduction to the spiritual life in the Christian tradition'. Such high praise is certainly warranted.

The first thing to say is that this book is not a kind of digest of Patristic theology. Rather it consists of twenty short chapters which distil a lifetime's knowledge and love of the wisdom to be found in ancient writings from Ignatius of Antioch through to Bernard of Clairvaux and beyond. By this means, the author sheds light on matters which have concerned and at times perplexed Christians down the centuries. Here you will find real help on such matters as the place of the body in Christian thought, Holy Warfare and Holy Reading. There are several chapters on prayer and one on the place of silence, a silence which is far more than the absence of noise.

As will be obvious, this is a book written from within the Catholic tradition and the author's treatment of certain topics will be unfamiliar to some. Thus, the chapter on Conversion of heart tackles the subject of prayer from the standpoint of a fundamental readiness to offer ourselves as whole persons to a God who mysteriously offers his whole self to us. This is a book to read carefully and prayerfully, to return to again and again. This is a book which sweeps away denominational barriers and which takes us to the beating heart of authentic Christian faith and practice.

This is a rare treasure. Buy it, read it, cherish it, but above all benefit from it.

Howard Bigg

Cambridge

Tomlin, G. (2011). The Prodigal Spirit. London: Alpha Publications.

I have to admit to being drawn to this book at least partly by the title. Whereas I could get an instant handle on 'The Provocative Church', and warmed to the somewhat subversive title, I was intrigued as to how the Spirit could be 'Prodigal'. Was this just an attempt to evoke the author's former title in the minds of potential readers, or does the book offer fresh insights in biblical pneumatology? My answer is that it's probably a bit of both, but don't let that put you off from reading what is a far reaching and accessible treatment of the central role of the Holy Spirit in human life, Christian faith, the world and the Church.

Although the focus of this book is the activity of the Holy Spirit, the author is determined to set his discussion in a Trinitarian framework, and it's from this that the book's title springs. In 
his introduction Tomlin draws on the Parable of the Prodigal Son and argues for several resonances between Jesus' story and a theology of the Spirit. The following chapters are built on the understanding that the Father sends out the Spirit into a world that has largely turned its back on him. The Spirit is lavish and generous (though not reckless), giving away the Father's good things, with the sole intent of drawing 'the whole of creation into the knowledge of the love of God, which is the love between the Father and the Son' (10); a 'returning' (to evoke the prodigal story) to the embrace of the Father's love.

From here, Tomlin focuses on seven specific arenas in which we can discern this central work of the Spirit and draws implications in each case. He begins with human identity, and in this chapter gives a brief overview of the filioque debate between Eastern and Western theology before arriving at a description of some modern theologies of the Spirit. The chapter visits in more depth the concept of the 'Prodigal Spirit', reinterpreting Karl Barth's Christological reading of the Parable of the Prodigal Son through the lens of Ireneus's description of the Son and the Spirit as the 'two hands of God.' The Spirit, Tomlin argues, confirms in us our identity as children of God such that, 'it is not so much a theology of the Spirit that we need as a theology in the Spirit' (35).

The author expounds his theology in the following four chapters, dealing with calling, experience, character and evangelism in turn. Key to the discourse in these chapters is the understanding that the Spirit as 'first fruit' of the age to come (Romans 8:23) is more than simply a pledge or sign of the kingdom. In the Spirit we are caught up in the creative and redemptive activity of God, such that we can taste the new creation. This impacts our sense of purpose, our experience of God, our character and our desire to engage in the Spirit's evangelistic mission. The chapter dealing with evangelism is perhaps a bit too Alpha-centric, but maybe we can forgive Tomlin for this given his church connections.

Chapter 6, in my view the strongest and most interesting chapter, focuses on the Holy Spirit and the world. I was particularly pleased to see that this chapter precedes a discussion of the Church, challenging the heretical notion that the Church carries the Spirit into the world. Also refreshing is to find a book aimed at a wide readership that deals with issues of community transformation, work, family, politics and the environment; viewing all (and more) as arenas of the Spirit's activity.

Following such a strong chapter I was somewhat disappointed with the final chapter discussing the Church. Not that I found anything there to disagree with; it's just that discussions of the Church's identity and purpose as described in the Nicene Creed (One, Holy, Catholic and Apostolic) can be found elsewhere and there is nothing new here. I would have been interested to explore how the concept of the Prodigal Spirit can help us to grapple with the big questions that are currently vexing the national and international Church, such as the ministry and authority of women in the church and the debates surrounding human sexuality. How is the Spirit leading us into all truth? Is the Church 
catching up with what the Spirit has been doing in the world? And how does all of this reflect the central activity of the Prodigal Spirit in returning all people to the embrace of the Father in his love for the Son? Sadly, none of this ground is visited and, given the 'Prodigal' premise of the book, I found it to be a striking omission.

That said, Tomlin has delivered a well constructed and argued book that will appeal to a wide readership and, in particular, to anyone interested in contemporary discussions in pneumatology or missiology. Despite the provocative title, it is largely a 'safe' book that won't ruffle too many feathers, but Tomlin offers some helpful insights that merit further reflection.

Malcolm Chamberlain

Archdeacon of Sheffield

\section{Wessels, A. (2013). The Torah, The Gospel and the Qur'an: Three Books, Two Cities, One Tale. Grand Rapids: Eerdmans.}

Taking his starting point from Dickens' A Tale of Two Cities, Wessels, a Presbyterian minister and emeritus professor of religion at the Free University of Amsterdam engages in a scholarly conversation with the sacred texts of Judaism, Christianity and Islam. His central organisational metaphor is the idea of two cities: one where God rules and one where his rule is ignored. Although Wessels recognises that any binary distinction is invariably overly simplistic, he uses the concept to trace the story of human and divine interaction in the city where God reigns (Jerusalem, Medina) and the city where his rule is challenged (Babylon, Rome, Mecca).

This book is a model of respectful interfaith conversation. Wessels does not seek to denigrate, or score points to defend Christianity at a cost to either Islam or Judaism. His central concern is to look for points of common connection, areas of mutual understanding and potential respect for each other. Although I was not completely convinced by his reasoning in recognising that Mohammed is a Prophet, I nevertheless found his approach very helpful for my own interfaith engagements. The discussion of Islamic understandings of the death of Jesus was particularly pertinent in this regard. What is also striking is Wessels is ready to challenge received interpretations of both Christian and Islamic doctrine, especially in his discussion of records of violence in sacred texts.

Wessels is clearly a master of both Islamic and Christian doctrine and scriptures, and although his discussion of the Torah is perhaps the weakest of the three strands he carefully weaves together, nevertheless this is an excellent book that should be essential reading for any Christian (indeed any person of faith) who wishes to engage in conversation across religious divides. The strongest personal challenge I encountered in the book was his discussion of Abraham's intercession for Sodom and Gomorrah, and the application that we should all be fervent in our intercession for mercy to be shown to the unrighteous. The book 
does achieve its central aim of demonstrating that violence perpetrated in the present era in the name of religion stems from a misunderstanding of the sacred texts, but I was left with a slight feeling of disappointment once I had finished reading. A final chapter that encouraged a clearer, bolder vision of building the city of God would have helped bring Wessels' excellent study to a stronger conclusion. That omission aside, it is nevertheless an absorbing and stimulating read, and I would highly recommend it.

Tom Wilson

Anvil Reviews Editor 